\title{
Adjuvants for a new generation of vaccines
}

\author{
Anthony C AlLison, DPhil, BM, FRCPATh, NOELENE E Byars, MSC
}

\begin{abstract}
AC Allison, NE Byars. Adjuvants for a new generation of vaccines. Can J Infect Dis 1992;3(Suppl B):84B-93B. Subunit antigens of viruses and other infectious agents in their natural configuration can be produced by recombinant DNA technology. To elicit protective immunity such antigens have to be administered with adjuvants that elicit cell-mediated immunity, including genetically restricted cytotoxicity, and that produce high affinity antibodies of protective isotypes. Antibodies of such isotypes (immunoglobulin G2a [IgG2a] in the mouse and IgG1 in humans) efficiently activate complement and effect antibody-dependent cell-mediated cytotoxicity. Naturally occurring adjuvants such as lipopolysaccharide and muramyl dipeptide (MDP) are pyrogenic and produce uveitis and arthritis in susceptible experimental animal and human recipients. Synthetic analogues of MDP and monophosphoryl lipid A (MPL) retain adjuvant activity with reduced side effects. Adjuvants increase the expression of class II major histocompatibility complex on antigen-presenting cells and cytokine production: interferon-gamma augments the production of IgG2a antibodies in the mouse. Dispersion of antigens in water-oil emulsions, immunestimulating complexes or liposomes also increases immunogenicity, at least partly by targeting antigens to antigen-presenting cells. Inclusion of MDP analogues or MPL in such systems constitutes adjuvant formulations, such as MDP-A. When used with a variety of recombinant and other subunit antigens, such adjuvants elicit protective immunity in experimental animals. This strategy improves vaccines already in use (eg, influenza and hepatitis B) and makes possible new vaccines (herpesviruses, simian and human immunodeficiency viruses, respiratory syncytial virus and acellular pertussis).
\end{abstract}

Key Words: Adjuvants, Monophosphoryl A, Muramyl dipeptide vaccines

\section{Adjuvants pour une nouvelle génération de vaccins}

RÉSUMÊ: La technologie de l'ADN recombinant permet de produire des vaccins à partir de sous-unités antigéniques virales ou de d'autres agents infectieux tout en gardant leur configuration naturelle. Pour induire l'immunité protectrice, ces antigènes doivent être administrés avec des adjuvants qui stimule l'immunitẻ cellulaire incluant la cytotoxicité génétiquement limitée et la production d'anticorps à forte affinité d'isotypes protecteurs. Les anticorps de tels isotypes (immunoglobine G2a chez la souris et immunoglobine G1 chez l'homme) activent efficacement le complément et produisent une cytotoxicité à médiation cellulaire liée à la présence d’anticorps. Les adjuvants naturels tels les lipoplysaccharides et le muramyl dipeptide (MDP) sont pyrogènes et provoquent l'uvéite et l'arthrite chez l'animal expérimental et l'homme sensible. Les analogues synthétiques du MDP et le lipide monophosphoryle A (MPL) conservent leur pouvoir adjuvant mais ont des effets secondaires moindres. Les adjuvants augmentent l'expression du complexe majeur d'histocompatibilité de classe II sur les cellules qui présentent les antigènes et la production de cytokines: l'interféron augmente la production d'anticorps IgG2a chez la souris. En ciblant les antigens sur les cellules qui présentent les antigens, la dispersion des antigènes dans des êmulsions d'eau et d'huile, les complexes immunostimulateurs ou les liposomes augmentent également l'immunogénicité. L'introduction des analogues MDP ou MPL dans de tels systèmes permet la production d'adjuvant tel que MDP-A. Quand ils sont utilisés avec une variété de recombinants et autres antigènes fragmentés, ces adjuvants provoquent une immunité protectrice chez l'animal expérimental. Cette stratégie améliore les vaccins existants tels ceux contre la grippe et l'hépatite B et donne lieu à de nouveaux vaccins contre l'herpèsvirus, les virus de l'immunodéficience humaine et simien, le virus respiratoire syncytial et la coqueluche acellulaire. 
In MPROVED AND NOVEL VACCINES ARE URGENTLY NEEDED AS they possibly could help prevent the spread of human immunodeficiency virus (HIV), protect against infection-susceptible groups of humans (including young children and the elderly) and eliminate some cancers, eg, primary hepatocellular and nasopharyngeal carcinoma. New methods for producing antigens have been developed, including recombinant DNA technology, exemplified by hepatitis B virus surface antigen and site-specific mutated pertussis toxin, and glycoconjugates, exemplified by Haemophilus influenzae vaccine. Moreover, understanding of the immune system has greatly advanced in the past few decades; the challenge is how to use this information to pro- duce a new generation of safe and efficacious vaccines.

Subunit antigens efficiently elicit cell-mediated and humoral immune responses only when administered with adjuvant formulations. These can be defined as formulations that augment cell-mediated and humoral immune responses to antigens. The formulations frequently have two components, an 'adjuvant' (eg, a muramyl dipeptide [MDP] or lipopolysaccharide [LPS] analogue) and a 'vehicle' (eg, a squalane emulsion or liposome preparation). The term 'vehicle' is used to make the distinction from a 'carrier', which is an immunogenic molecule bound to a molecule of low immunogenicity able to augment immune responses to the latter; for example, a protein bound to a bacterial capsular polysaccharide.

Two adjuvant formulations have a long history. One is based on mineral oil emulsions, with or without mycobacteria, and the second on adsorption of antigens to aluminum salts. In recent years three adjuvant formulations have been developed: liposomes, immunestimulating complexes (ISCOMs) and squalene or squalane emulsions. Although several types of surfaceactive agents have adjuvant activity, most attention has been focused on saponin-like quil A molecules in Iscoms and Pluronic block copolymers which are used to make stable squalene or squalane emulsions. Analogues of MDP and LPS have been produced with the objective of preserving adjuvant activity while minimizing side effects. In experimental animals, promising results have been obtained with the new adjuvant formulations, and trials of their efficacy in humans have been initiated.

To allow selection of the most appropriate adjuvant for use in a particular vaccine, it is necessary to establish the role of adjuvants and the side effects to be avoided. A clear understanding of the latter may facilitate regulatory approval. Fortunately there are signs that the hitherto inflexible opposition of regulatory authorities to the use of adjuvants other than aluminum salts in human vaccines is changing.

\section{AFFINITIES AND ISOTYPES OF ANTIBODIES}

Traditionally the efficacy of adjuvants has been judged by the levels of antibodies elicited (using a convenient test, such as ELISA or hemagglutination).
While these assays have provided useful information, they should be supplemented by other measures of the quantity and quality of antibodies elicited. Preferably, antibody levels should be quantified by tests relevant to function, such as neutralization of bacterial toxins or viruses. Because of potential problems with solid phase assays, at least some measurements of antibody levels using fluid phase assays should be made. In addition to the quantities of antibodies elicited by a vaccine, two properties of the antibodies are likely to be important for protection: their affinity for antigen and their isotype. To neutralize a virus or bacterial toxin, antibodies should bind them with sufficiently high affinity. If the complexes are not removed by phagocytic cells, antibodies must bind to a virus or toxin with an affinity of at least the same order as the natural receptor. The authors have developed methods for measurement of the quantities and affinities of antibodies in the fluid phase useful in studying the efficacy of vaccines (1).

Another important property of antibodies is their isotype. Antibodies of the immunoglobulin G (IgG) class pass from the vascular to the extravascular compartment more easily than those of the IgM class; only the former are transferred across the placenta or by milk to fetuses and newborn animals. Antibodies of some isotypes efficiently activate complement, bind to high affinity receptors on monocytes and act synergistically with antibody-dependent effector cells (ADCC), to produce cytotoxicity. Examples are IgG2a antibodies in mice and IgG1 antibodies in humans, both of which bind to high affinity FcyI receptors (2). Studies with isotype-switch variants of murine monoclonal antibodies (which have the same Fab regions, so binding to antigen is comparable) show that IgG2a antibodies confer better protection against tumours than those of other isotypes (3). Antibodies of the IgG2a isotype are also involved in protection against at least some infectious agents (4). Studies with 'reshaped' human antibodies, genetically constructed to have antigen-binding hypervariable regions like those of rodent monoclonals, confirm the superiority of the human $\operatorname{IgG} 1$ isotype in ADCC-mediated lysis (5). The desirability of developing an adjuvant formulation that preferentially elicits high affinity antibodies of the $\lg$ G2a isotype in mice and IgG 1 in humans is apparent.

Antibodies elicited should be directed to determinants exposed in native antigens; modern adjuvants augment the formation of such antibodies whereas Freund's adjuvant can denature antigens and elicit antibodies against internal determinants (6).

\section{CELL-MEDIATED IMMUNITY}

Helper $\mathrm{T}$ lymphocytes are required for the formation of antibodies against most antigens. In addition, cytotoxic T lymphocytes can lyse infected cells or produce mediators, such as interferon-gamma (IFN- $\gamma$ ) following interaction with antigen in a genetically restricted situ- 
ation (7). Cytotoxic T lymphocytes able to lyse autologous cells expressing several antigens of HIV are demonstrable in infected persons (8), although it is unknown whether they have a protective role.

It is likely, therefore, that for optimal protection against some infectious agents, eg, herpesviruses and possibly HIV, the elicitation of cell-mediated immunity is desirable. Tests for cell-mediated immunity should include not only delayed hypersensitivity, but also proliferative responses to the antigen and release of IL-2 (9) and IFN- $\gamma$. Cytotoxicity for autologous or syngeneic infected target cells should also be studied. If mice or rats are used, syngeneic target cells are readily available. With outbred species, such as humans and subhuman primates, B cells transformed by Epstein-Barr virus and transfected with a vaccinia virus vector expressing the antigen under consideration (eg, HIV antigens [8]) can provide autologous target cells for studies of genetically restricted cell-mediated cytotoxicity.

According to traditional wisdom, replicating viruses are required to elicit cytotoxic T lymphocyte responses, but that is not the case - recombinant envelope glycoprotein of HIV in ISCOMs elicits $\mathrm{CD}^{+}$major histocompatibility complex class I restricted cytotoxicity in mice (10). The authors found that recombinant gpD of herpes simplex virus-2 in Syntex adjuvant formulation elicited $\mathrm{CD}^{+}$, class II restricted $\mathrm{T}$ lymphocytes in guinea pigs. Hence, subunit vaccines in an efficacious adjuvant can elicit cytotoxic $\mathrm{T}$ cell responses.

\section{UNDESIRABLE EFFECTS OF ADJUVANTS}

The first complication of adjuvant use is acute tissue damage at the injection site or a later granulomatous reaction. Many surface-active adjuvants produce tissue damage at injection sites. A convenient test is measurement of creatine phosphokinase in the circulation after intramuscular injection (9). Limits of circulating creatine phosphokinase acceptable to regulatory authorities for injections of drugs and vitamins have been defined. Granulomas can be assessed by histological examination at various times following vaccine injection or by measurement of leukocyte enzymes following intramuscular injection (11). Even alum produces an appreciable granulomatous response at the injection site (much greater than is elicited by MDP adjuvant formulation [MDP-A]). The current authors have never observed lesions at either the primary or secondary injection sites in experiments in which guinea pigs were vaccinated subcutaneously with repeated doses of antigen and the threonyl analogue of MDP discussed below. At necropsy the injection sites were difficult to locate, contrasting the necrotic lesions at injection sites described by Nagao and Tanaka (12) using [ala ${ }^{1}$ ]-MDP.

A second undesirable effect of adjuvants is pyrogenicity. In fact, a regulatory requirement of biological products introduced into humans is that they should not be pyrogenic. Naturally occurring adjuvants, such as MDP and LPS, are pyrogenic. However, some synthetic analogues of MDP, including murabutide (13) and N-acetylmuramyl-L-threonyl-D-isoglutamine ([Thr $\left.{ }^{1}\right]$ MDP) (9), are potent adjuvants with greatly reduced pyrogenicity compared with naturally occurring MDP. The monophosphoryl derivative of lipid A retains adjuvant activity with reduced pyrogenicity (14).

Human infections with Gram-negative bacteria may produce Reiter's syndrome, a complex including anterior uveitis, arthritis and urethritis. Although full-blown Reiter's syndrome is rare, its components, including an influenza-like syndrome, muscle cramps and generalized joint discomfort, are common. Certain individuals, particularly those of the HLA-B27 haplotype, genetically are predisposed to develop one or more components of Reiter's complex (15); this can happen when they are exposed to small amounts of bacterial products or given certain drugs such as levamisole hydrochloride. Some Reiter's symptoms (an influenza-like syndrome and generalized joint discomfort) can be produced by injection of $1 \mathrm{mg}$ or more of muramyl peptide analogues into humans (16). If an adjuvant is to be used in millions of people, some genetically predisposed, it might produce or exacerbate Reiter's symptoms (the most serious is anterior uveitis). Hence, separation of adjuvant activity from capacity to induce anterior uveitis is a major safety requirement.

The rabbit and cynomolgus monkey provide appropriate experimental models. Small doses of LPS or MDP injected intravenously in the rabbit increase vascular permeability in the eye, as shown by passage of fluoresceinated macromolecules into the anterior chamber (17). Histological examination shows leukocyte emigration into the uveal tract that can lead to irreversible changes. Synthetic analogues of MDP were compared for their capacity to produce uveitis and to function as adjuvants (17). Nor-MDP, which was used in a clinical trial with $\beta H C G$ in Australia (18), was among the analogues with the highest capacity to produce uveitis in rabbits (17). Repeated administration of nor-MDP produced granulomatous inflammation in the eye and blindness in cynomolgus monkeys. The threonyl analogue of MDP was found to be a potent adjuvant with low pyrogenicity and low capacity to produce uveitis (17). MDP, murabutide and lipophilic derivatives such as muramyltripeptide-phosphatidyl-ethanolamine (MTP-PE) activate macrophages to produce nonspecific resistance to infection while [Thr ${ }^{1}$ ]-MDP lacks this activity (19). Production of mediators, including prostaglandins, by activated macrophages and endothelial cells likely contributes to uveitis pathogenesis (17). The lipophilic MDP analogues tested were potent in the induction of uveitis (17), and administering them in liposomes aggravated this activity. While the use of the lipophilic MTP-PE in cancer patients (16) ethically is justifiable, the safety of this formulation in widely used adjuvants is questionable. 
MDP and some derivatives can produce adjuvanttype arthritis in the rat (20). It is essential that adjuvants for human use do not have this activity; [Thr $\left.{ }^{1}\right]$ MDP does not produce adjuvant arthritis in the rat (9).

\section{MINERAL OIL EMULSIONS}

The study of adjuvants was initiated in 1916 when Le Moignac and Pinay found that suspending Salmonella typhimurium in mineral oil increased antibody function. Oil-based adjuvants have since been used to increase humoral responses of farm animals to many inactivated bacterial and viral vaccines (21). Freund's incomplete adjuvant (FIA) is a water-in-mineral oil emulsion stabilized with the detergent arlacel A while Freund's complete adjuvant (FCA) also contains killed mycobacteria (22). In general, protein antigens in FIA elicit antibody formation but not delayed-type hypersensitivity; protein antigens in FCA also elicit delayed-type hypersensitivity. Freund's adjuvants have been used widely in laboratory animals to elicit high levels of antibodies, cell-mediated immunity and protection against challenge with viable microorganisms. FCA has not been approved for use in human or veterinary vaccines because it elicits tuberculin hypersensitivity and granulomatous reactions at injection sites. The use of FCA in laboratory animals now is being discouraged, and an efficacious and safe alternative urgently is needed.

\section{ALUMINUM SALTS}

Glenny and colleagues (23) precipitated diphtheria toxoid by potassium alum and found that the precipitate elicited formation of antitoxin much more effectively than did the unprecipitated toxoid. This was the first of many observations showing that aluminum salts, especially aluminum hydroxide and aluminum phosphate, are adjuvants. Aluminum hydroxide (alhydrogel) is the only adjuvant currently authorized for human use by the United States Food and Drug Administration. The efficacy of aluminum hydroxide in increasing antibody responses to diphtheria and tetanus toxoids is well-established. Hepatitis B virus surface antigen, both serum-derived and recombinant, is adjuvanted with alum. While the usefulness of alum is well-established for some applications, it has limitations; for example, it is ineffective for influenza vaccination (24), inconsistently elicits cell-mediated immunity (25) and not all antigens are adsorbed to alhydrogel. The antibodies elicited by alum-adjuvanted antigens are mainly of the IgG 1 isotype in the mouse (25), which may not be optimal for protection. Adsorption to alum can denature proteins (26) and alum can increase the formation of $\operatorname{IgE}$ antibodies in rabbits and rodents (27). IgE antibodies can produce hypersensitivity.

\section{SAPONIN AND IMMUNE-STIMULATING COMPLEXES}

Saponins are surface-active agents widely distributed in plants. A group of triterpene glycosides extracted from the South American tree Quillaia sapon- aria, termed quil A, has adjuvant activity (28). Saponin is a potent adjuvant for strong antigens but is ineffective for weak antigens (29). Saponins have been used in several veterinary vaccines, including that for foot-andmouth disease virus (28). Saponin is also an effective adjuvant for vaccines against parasites, including Trypanosoma cruzi and Plasmodium yoelii (30).

Nevertheless, saponin has a number of undesirable side effects - it is irritating, pro-inflammatory, binds to cholesterol and lyses red blood cells (29) - and thus ways to retain the adjuvant activity but diminish the negative effects have been sought. One approach has been the production of Iscoms which were originally described by Morein et al (31) as particles consisting of quil A and membrane proteins. The preparation of Iscoms allowed reduction in the quil A concentration required for adjuvant effects. Later studies showed that lipids are also essential for formation of the regular cage-like structures characteristic of Iscoms, whereas preparations lacking lipids tend to form aggregates or micelles (32).

ISCOM preparations have been reported to increase antibody responses to several viral membrane proteins, compared with responses obtained with aqueous or liposome preparations of the antigens. Proteins from bovine herpesvirus type 1, cytomegalovirus, hepatitis B virus, Epstein-Barr virus and canine distemper virus have been tested with ISCOMs (33). Iscoms have also been used to improve an equine influenza vaccine, and a commercial Iscom-influenza vaccine now is licensed for use in Sweden. ISCOMs containing the recombinant envelope protein of HIV (gp 160) elicited $\mathrm{CD}^{+}$cytotoxic $\mathrm{T}$ lymphocytes in mice (10).

ISCOMs are potent adjuvants for many antigens. Several questions concerning Iscoms remain unanswered; for example, are they suitable for antigens other than the viral envelope glycoproteins for which they were developed? Quil A is heterogeneous, and the chemical entities in it are only partially defined. The glycoside required to make ISCOMs is different from those increasing immune responses (personal communication). It will be difficult to assemble a full toxicology profile, including tests for carcinogenicity that likely will be requested by regulatory authorities for general use. Although largescale production of IsCOM vaccines is feasible, it is easier to mix antigens with preformed emulsions. Monkeys immunized with simian immunodeficiency virus (SIV) glycoproteins in IScOMs (34) were sensitized and showed acute hypersensitivity when challenged with virus; animals immunized with the antigens in MDP-A showed protection but were not sensitized. Presumably ISCOMs, like saponin, can elicit IgE antibodies, but whether this would be a problem in practice is unknown.

\section{MURAMYL DIPEPTIDE ANALOGUE FORMULATION}

The mycobacteria in FCA have several disadvantages; they contain tuberculin and other proteins, causing animals to become sensitized after a single 


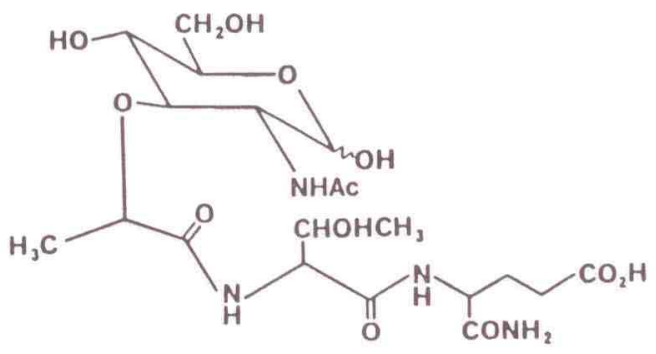

N-Acetyl-muramyl-L_-threonyl-D-isoglutamine

$$
\left(\mathrm{CH}_{2}-\mathrm{CH}_{2}-\stackrel{\stackrel{\mathrm{O}}{\mathrm{O}})}{\stackrel{\mathrm{E}}{\mathrm{H}}-\mathrm{O}-\text { - polyethylene chain }}\right.
$$

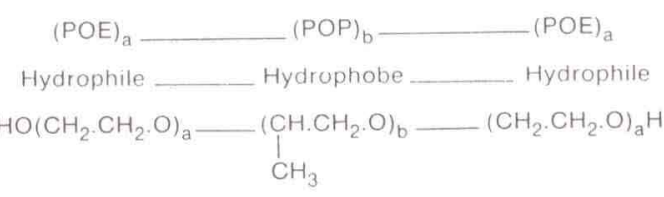

Structure of pluronic polyols

Figure 1) Above Structure of the muramyl dipeptide (MDP) analogue used in MDP-A. Middle Diagram of the way in which the oxygen atoms of the polyoxythylene chains are able to form hydrogen bonds with acceptor groups of peptides. Below Structure of the L-121 block copolymers of polyoxyethylene ether (POE) and polyoxypropylene ether (POP) used in MDP-A

injection; and a second injection of FCA produces a massive delayed-type hypersensitivity response. It was a considerable advance when Ellouz et al (35) showed that the minimal adjuvant-active component of the mycobacterial cell wall is MDP ( $\mathrm{N}$-acetylmuramyl- $\mathrm{L}-$ alanine-D-isoglutamine). When protein antigens are administered to guinea pigs in FIA and MDP, delayedtype hypersensitivity and antibodies of the $\gamma 2$ isotype are elicited.

As discussed above, MDP has undesirable effects, including pyrogenicity and capacity to induce anterior uveitis and arthritis. Over $130 \mathrm{MDP}$ analogues were synthesized at Syntex Research (California) in an attempt to separate adjuvant activity from side effects. The threonyl analogue of MDP, N-acetylmuramyl-Lthreonyl-D-isoglutamine, shows the greatest separation of adjuvant activity from side effects so far obtained $(9,17)$ (Figure 1). This analogue, therefore, was selected as an acceptable counterpart of mycobacteria in an adjuvant formulation (9). The current authors' next challenge was to develop an alternative to the mineral oil emulsion of Freund's adjuvant suitable for human use.

After much experimentation with liposomes, several oil preparations and various surface-active agents, the authors found that squalene or squalane emulsions,

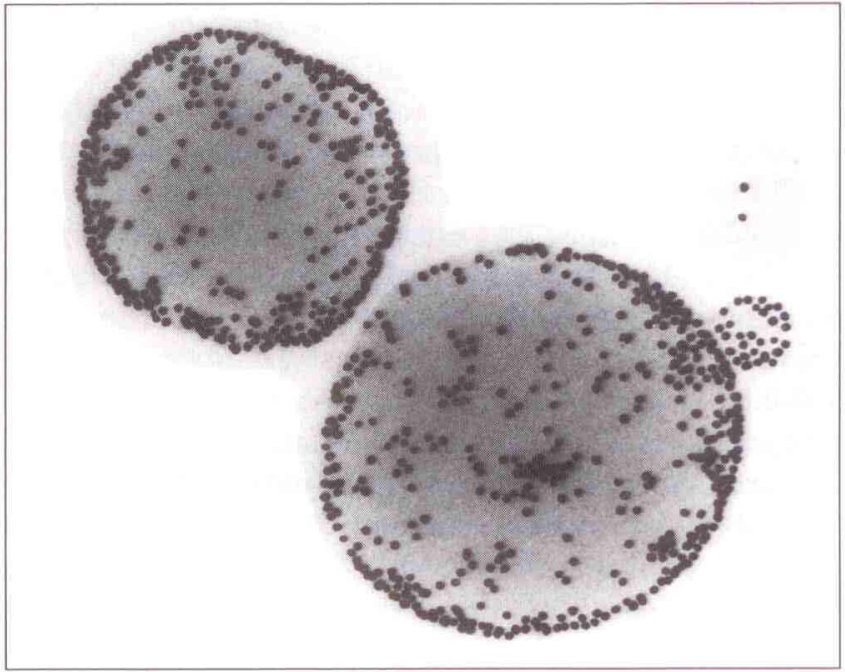

Figure 2) Electron micrograph (x30,000) of a pluronic L-121 squalane emulsion showing antigen (ovalbumin) labelled with colloidal gold concentrated on the surface of lipid spherules in an aqueous suspension

prepared with the Pluronic block-copolymer L-121 and stabilized with a small amount of Tween 80 , provided a versatile vehicle for antigens (9). Hunter et al (36) had used L-121 and related molecules with mineral oil as adjuvants. In L-121 a central block of polyoxypropylene is hydrophobic while two flanking blocks of polyoxyethylene are hydrophilic because of hydrogen bonding with water (Figure 1). Since it is surface-active, L-121 associates with membranes, but it does not penetrate into membranes and disrupt their structure, unlike saponins which bind cholesterol and are cytolytic. Squalane is saturated and stable in formulation, unlike squalene, which is unsaturated and becomes oxidized. The authors' microfluidized squalane-L-121 emulsion is remarkably stable, even when frozen, and does not produce reactions at injection sites in humans (unlike squalane emulsions prepared with higher concentrations of membrane-active detergents).

The workers believe the squalane L-121 emulsion as a vehicle for antigens is effective because antigens are concentrated on the surface of the squalane microspheres and are retained there partly because they are amphipathic and partly by hydrogen bonding to L-121 (Figures 2,3). The squalane L-121 emulsion system, therefore, is more versatile than squalane emulsions lacking the block copolymer and is more versatile than liposomes, the structure of which has to be optimized for each antigen. The squalane L-121 microsphere particles also activate complement and migrate from injection sites to lymph nodes of the drainage chain. The $\mathrm{C} 3 \mathrm{~b}$ on the surface of the microspheres should target them to follicular dendritic cells, major antigen-presenting cells. A depot of antigen on follicular dendritic cells is more important for immunogenicity, as well as better for the patient, than a depot at the injection site. 
Thus, the function of the squalane-L-121 emulsion is targeting antigens to antigen-presenting cells. The function of the MDP analogue is to induce expression of cytokines and increase expression of major histocompatibility genes and intracellular adhesion molecules, which are required to trigger cell-mediated immune responses. The combination of the threonyl analogue of MDP with the squalane-L-121 emulsion is termed MDP-A, also known as Syntex adjuvant formulation.

\section{LIPOPOLYSACCHARIDE AND MONOPHOSPHORYL LIPID A}

Gram-negative bacteria such as escherichia, salmonella and pseudomonas have endotoxins which induce fever, changes in leukocyte count, hypotension, shock and uveitis. The endotoxins are LPS, consisting of a hydrophilic polysaccharide covalently linked to the hydrophobic lipid A component. LPS has potent immunological adjuvant activity as well as inducing macrophage activation and nonspecific stimulation of immune responses. The structures of lipid A from escherichia and salmonella have been elucidated (37) and are quite similar (Figure 4).

Observations with synthetic lipid A and analogues confirm that the biological activity of LPS resides in the lipid A portion of the molecule. Chemical modifications of the lipid A structure have been made to decrease the toxicity without reducing adjuvant activity. Synthetic monophosphoryl lipid A of $E$ coli has been synthesized by Imoto et al (38), while Ribi et al (14) chemically have removed the phosphate moiety from the C-1 position of the toxic diphosphoryl lipid A of salmonella. Monophosphoryl lipid A is less toxic than the diphosphoryl molecule, but retains much of the adjuvant and mitogenic activity of LPS, and induces nonspecific protection against bacterial infections (14). Monophosphoryl lipid A, formulated in a squalane emulsion or in liposomes, has useful adjuvant activity.

\section{LIPOSOMES}

Allison and Gregoriadis (39) showed that liposomes increase immune responses to bacterial toxoid. Liposomes are versatile vehicles since their size, composition, surface charge and structure (multilamellar or unilamellar) can be varied. Antigens can be entrapped within liposomes or bound to their surface, and adjuvants such as monophosphoryl lipid A or lipophilic MDP analogues can be used with liposomes. Gregoriadis (40) has reviewed many applications of liposomes for this purpose.

\section{TARGETING VACCINES TO ANTIGEN-PRESENTING CELLS}

The traditional view was that adjuvants such as mineral oil emulsions or aluminum hydroxide form at the injection site depots from which antigen slowly is released; however, excision of the injection site after

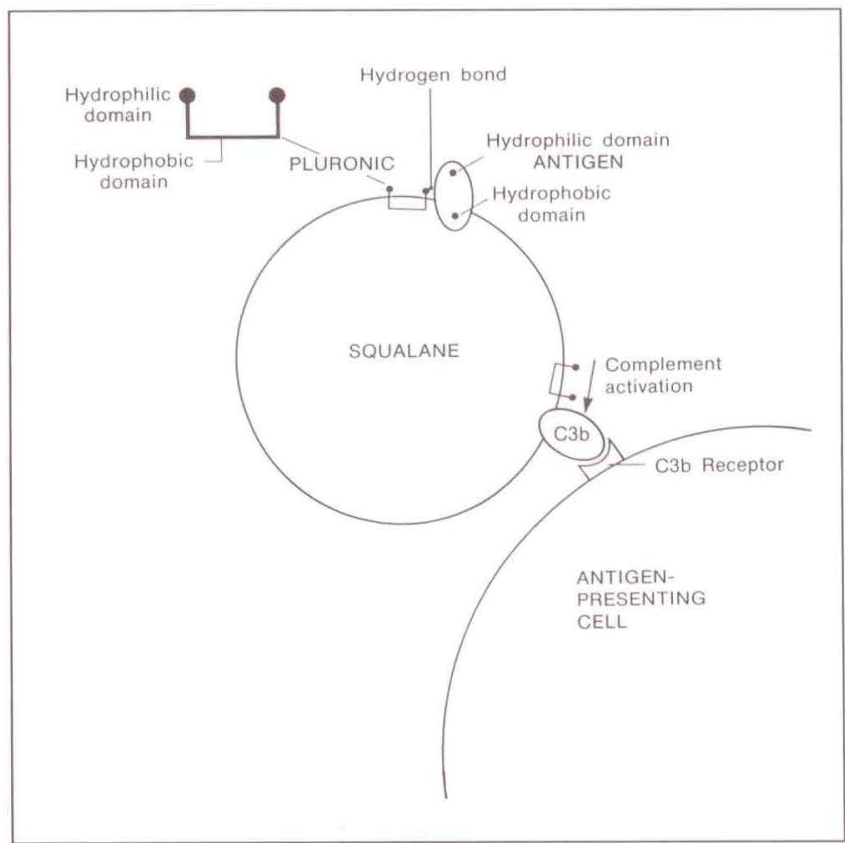

Figure 3) Diagram of the putative structure of a microsphere in the adjuvant formulation showing the antigen held at the interface partly because of its amphipathic character and partly because acceptor groups in the antigen form hydrogen bonds with the pluronic polymer. The pluronic polymer also activates complement by the alternative pathway and C3b formed is retained at the surface of the microspheres, facilitating their binding to $\mathrm{C} 3 \mathrm{~b}$ receptors on antigen-presenting cells

three days was found to have little effect on immune responses. The authors performed the first systematic study of cells responding to antigens and adjuvants using cell transfers $(41,42)$, and showed that adjuvants such as LPS or Bordetella pertussis initially interact with antigen-presenting cells and not lymphocytes. However, adjuvants could not bypass the requirement for helper T lymphocytes (43). More recently, antigenpresenting cells have been better defined. While cells of the monocyte and macrophage lineage can function as antigen-presenting cells when activated (for example during infections), three other cell types function as antigen-presenting cells under physiological conditions, such as in a human responding to vaccine antigens.

Langerhans' cells: Cells of the Langerhans' cell lineage originate in the bone marrow, migrate through the blood to the skin (remaining for about one week) and then migrate through afferent lymphatics to the $\mathrm{T}$ dependent areas of lymph nodes, where they are termed interdigitating cells (44).

Dendritic cells isolated from the spleen (45) have similar properties and may be of the same lineage. Because of possible confusion with follicular dendritic cells which have a different location and properties, the term 'Langerhans' cells' is used. Cells of this lineage efficiently present antigens associated with their surfaces; for example, contact-sensitizing chemicals and myelin basic protein elicit $\mathrm{T}$ lymphocyte-dependent immune responses (46). 


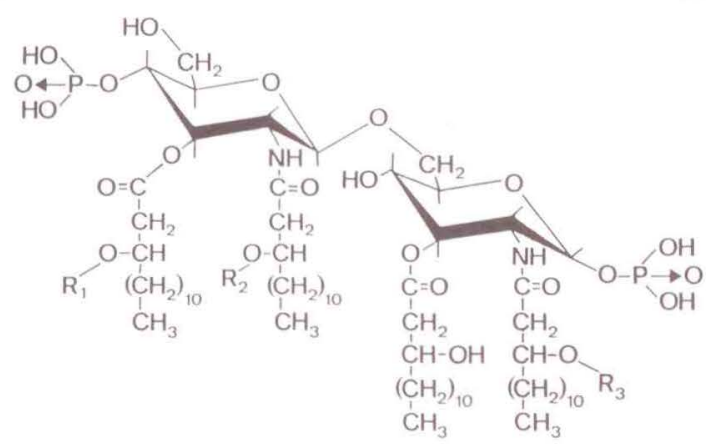

$$
\begin{aligned}
& \mathrm{R}_{1}=-\stackrel{\mathrm{I}}{\mathrm{C}}-\left(\mathrm{CH}_{2}\right)_{12}-\mathrm{CH}_{3} \text { or }-\mathrm{H} \\
& \mathrm{R}_{2}=-\mathrm{I}_{\mathrm{O}}^{\mathrm{C}}-\left(\mathrm{CH}_{2}\right)_{10}-\mathrm{CH}_{3} \text { or }-\mathrm{H} \\
& \mathrm{R}_{3}=-\mathrm{C}-\left(\mathrm{CH}_{2}\right)_{14}-\mathrm{CH}_{3} \text { or }-\mathrm{H}
\end{aligned}
$$

Figure 4) Structure of lipid A. In monophosphoryl lipid A, the phosphate group on the right side is missing (courtesy of Dr J Rudbach)

Follicular dendritic cells: Follicular dendritic cells (FDC) are found in lymphoid follicles in lymph nodes, spleen and other sites. Their branching cytoplasmic extensions are closely associated with B lymphocytes. FDC express CD4 and high affinity $\mathrm{C} 3 \mathrm{~b}$ receptors. Immune complexes activating complement injected into mice become localized on FDC, and this process appears to be required to generate $\mathrm{B}$ lymphocyte memory (proliferation of clones of B lymphocytes responding to antigen with consequent priming for a secondary response) (47). Immune complexes binding FDC become associated with beaded cell membrane extensions which are readily taken up by follicular B lymphocytes expressing class II major histocompatibility antigens (48). The antigen can be demonstrated for at least one week by immunocytochemistry in endocytic vacuoles within B cells; in such a compartment they may partially be digested for presentation to T lymphocytes.

B lymphocytes: Evidence recently has accumulated that B lymphocytes efficiently present antigens to T lymphocytes (49). In fact, depletion of B cells by repeated injections of antibody against the $\mu$-chain of immunoglobulin markedly decreases responses to antigens of T lymphocytes in peripheral lymphoid tissues. A major role of surface membrane immunoglobulin receptors for antigens on $\mathrm{B}$ cells may be to bind the antigen for subsequent $\mathrm{T}$ cell presentation. Targeting of antigens to FDC may be a crucial factor in the efficient presentation to B lymphocytes and, through them, to T lymphocytes. In secondary immune responses this occurs through the formation of complement-activating immune complexes. Adjuvant formulations can facilitate localization by activating complement - this is true of LPS and MDP-A: liposomes of compositions that activate complement are better adjuvants than those that do not. Such complement activation should be moderated to allow sufficient $\mathrm{C} 3 \mathrm{~b}$ on antigen-bearing micelles, emulsions or liposomes for targeting of associated antigens, but not sufficient complement activation at injection sites to elicit inflammatory lesions.

\section{SELECTION BY ADJUVANTS FOR THE PRODUCTION OF ANTIBODIES OF HIGH AFFINITY AND PROTECTIVE ISOTYPES}

For reasons discussed above, it frequently is desirable to elicit isotype antibodies of high affinities and protective isotypes, eg, IgG2a in the mouse. It has long been known that the use of particular adjuvants can influence the isotypes of antibodies. An example is the use of low doses of antigen with alum, B pertussis or saponin to produce IgE antibodies in the mouse. Antigens administered to guinea pigs in FIA mainly elicit antibodies of the $\gamma_{1}$ isotype whereas with the complete adjuvant $\gamma_{2}$ antibodies are formed (50). The authors have compared antibodies elicited by human serum albumin and recombinant human interleukin (IL)- $1 \alpha$ administered to mice in different adjuvants by the intraperitoneal and subcutaneous routes (6). Considerable differences were observed: FCA elicited high levels of antibodies (these were not of high affinity, with many directed to epitopes not exposed on the native molecule); MDP-A elicited the highest proportion of antibodies of the IgG2a isotype; antibodies against IL-1 were potent in neutralizing biological activity of the molecule (with cells from the mice used to produce monoclonal antibodies); and aluminum hydroxide and quil A elicited mainly antibodies of IgG1 $(25,29)$.

Thus, adjuvants can select for the isotype of antibodies formed. Moreover, production of hybridomas does not require the barbarous traditional procedure of immunizing intraperitoneally with FCA. Subcutaneous or intramuscular immunization with MDP-A or quil A, depending on the desired isotype, is effective equally (6). The use of FCA for laboratory animal immunization already is restricted in several large research centres and more humane adjuvants are similarly effective.

\section{ROLE OF CYTOKINES IN ISOTYPE SELECTION}

Until recently the mechanisms by which the formation of antibodies of particular isotypes are favoured were unknown. Evidence is accumulating that cytokines play a role in isotype selection in the mouse and in cultured human cells (51). IFN- $\gamma$ augments the production of IgG2a antibodies in mice, whereas IL-4 augments IgG1 and IgE antibodies, explaining why adjuvants that are designed to increase cell-mediated immunity - such as FCA and MDP-A - concurrently select for antibodies of the IgG2a isotype. Potent T cell-mediated responses to antigenic stimulation release IFN-g (from both the helper and cytotoxic subset of $\mathrm{T}$ cells) which augments the formation of IgG2a antibodies. Adjuvants which less consistently stimulate $\mathrm{T}$ cell responses, such as aluminum hydroxide and quil 
A, favour production of IgGl and IgE antibodies, presumably by stimulating release of more IL- 4 than IFN- $\gamma$.

\section{USE OF ADJUVANTS IN VACCINES}

Examples of modern adjuvant use in vaccines include MDP-A in inactivated virus vaccines for feline leukemia virus, simian acquired immune deficiency syndrome (52), SIV (53), and a recombinant HIV-1 vaccine in chimpanzees (54). In the absence of an efficacious adjuvant, little or no protection is observed. The same is true with subunit vaccines of herpesviruses. Recombinant gpD of herpes simplex virus- 2 in FCA elicits strong protection in guinea pigs against genital challenge with the virus; protection is not observed with other adjuvants (55). GpD in MDP-A also is highly protective in this model (56). The major surface glycoprotein of Epstein-Barr virus (gp340) in MDP-A protects cottontop tamarins against a 100\% lymphomagenic dose of the virus (57). In this model, alum and vaccinia constructs are less effective or toxic. MDP-A also is efficient at eliciting anti-idiotypic antibodies and protecting against B lymphomas in mice (58).

Two examples will suffice to illustrate that adjuvants can help to overcome the effects of age on immune responses. In general, infants and persons over the age of 65 show lower responses to vaccines than do older children and young adults. It is estimated that less than one-third of old recipients of influenza hemagglutinin show antibody responses (59). Alum is not an effective adjuvant for hemagglutinin (24). Syntex adjuvant formulation augments responses to hemagglutinin in mice, especially in very young and old animals (60). If this holds true in humans, the efficacy

\section{REFERENCES}

1. Kenney JS, Hughes BM, Allison AC. Determination of antibody affinity and concentration by solution-phase microradioimmunoassay. In: Zola H, ed. Laboratory Methods in Immunology. Boca Raton: CRC Press, 1990:209-16.

2. Unkeless JC, Scigliano E, Freedman VH. Structure and function of human and murine receptors for IgG. Ann Rev Immunol 1988:6;251-81.

3. Kaminski MS, Kitamura K, Maloney DG, Campbell MJ, Levy R. Importance of antibody isotype in monoclonal anti-idiotype therapy of murine B cell lymphoma. A study of hybridoma class-switch variants. J Immunol 1986:136;1123-30.

4. Wechsler DS, Konghshavn PAL. Heat-labile antibodies effect cure of Trypanosoma musculi infection in C57BL/6 mice. J Immunol 1986:137;2968-72.

5. Reichmann L, Clark M, Waldmann H, Winter G. Reshaping human antibodies for therapy. Nature 1988:332;323-7.

6. Kenney JS, Hughes BW, Masada MP, Allison AC. Influence of adjuvants on the quantity, affinity, isotype and epitope specificity of murine antibodies. J Immunol Methods 1989:121;157-66.

7. Morris AG, Lin Y-L, Askonas BA. Immune interferon release when a cloned cytotoxic T-cell line meets its correct influenza-infected target. Nature 1982:295;150-2. of influenza vaccines will be improved in populations where they are most needed. The fusion protein of parainfluenza 2 virus in MDP-A is an effective vaccine in laboratory animals.

Where hepatitis B virus is prevalent, eg, in SouthEast Asia and Africa, immunization of infants can prevent chronic infection which is associated with hepatitis and hepatocellular carcinoma. Mice of some genetic constitutions are low responders to hepatitis $\mathrm{B}$ surface antigen (61); MDP-A improves responses to hepatitis B surface antigen in young mice and overcomes inherited low responsiveness (62). A potent adjuvant, thus, can improve immune responses when they are deficient because of age or genetic constitution.

\section{PROSPECTS}

The mode of action of adjuvants is being defined in terms of contemporary immunology. Several efficacious adjuvant formulations have been developed which do not have limiting toxicity in experimental animals or humans. Studies of their efficacy in humans are in progress. The new adjuvants could improve vaccines already in use (eg, influenza and hepatitis B) and make possible the development of others (against herpesviruses, Rous sarcoma virus and HIV, for instance). Immunization against Epstein-Barr virus and cytomegalovirus before organ transplantation is desirable. In South-East Asian and African countries, immunization of infants against hepatitis B virus and EpsteinBarr virus could eliminate two common cancers, primary heptocellular carcinoma and nasopharyngeal cancer. In this way, the promise of recombinant and peptide antigens could be fulfilled.

8. Walker BD, Flexner C, Paradis TJ, et al. HIV-1 reverse transcriptase is a target for cytotoxic T-lymphocytes in infected individuals. Science 1988:240;64-6.

9. Byars NE, Allison AC. Adjuvant formulation for use in vaccines to elicit both cell-mediated and humoral immunity. Vaccine 1987:5;223-8.

10. Takahashi H, Takeshita T, Morein B, Putney S, Germain $\mathrm{RN}$, Berzofsky JA. Induction of $\mathrm{CD}^{+}$cytotoxic T cells by immumzation with purified HIV-1 envelope protein in Iscoms. Nature 1990:344;873-5.

11. Davies P, Allison AC. Secretion of macrophage enzymes in relation to the pathogenesis of chronic inflammation. In: Nelson DS, ed. Immunobiology of the macrophage. New York: Academic Press, 1976:427-50.

12. Nagao S, Tanaka A. Necrotic inflammatory reaction induced by muramyl dipeptide in guinea pigs sensitized by tubercle bacilli. J Exp Med 1985:162;401-12.

13. Chedid L, Parant MA, Audibert FM, et al. Biological activity of a new synthetic muramyl dipeptide adjuvant devoid of pyrogenicity. Infect Immun 1982:35;417-25.

14. Ribi E, Ulrich JT, Masihi KN. Immunopotentiating activities of monophosphoryl lipid A. In: Majde JA, ed. Immunophamacology of infectious diseases: Vaccine adjuvants and modulation of non-specific resistance. New York: Alan R Liss, 1987:101-12.

15. Geczy AF, Alexander K, Bashir HV, Edmonds JP, Upfold 
L, Sullivan J. HLA-B27, klebsiella and ankylosing spondylitis: Biological and chemical studies. Immunol Rev 1983:70;23-50.

16. Murray JL, Kleinerman ES, Cunningham JE, et al. Phase I trial of liposomal muramyl tripeptide phosphatidylethanolamine in cancer patients. J Clin Oncol 1989:7;1915-25.

17. Waters RV, Terrell TG, Jones GH. Uveitis induction in the rabbit by muramyl dipeptides. Infect Immun 1986:51;816-25.

18. Jones WR, Bradley J, Judd SJ, et al. Phase I clinical trials of a World Health Organization birth control vaccine. Lancet 1988:i; 1295-8.

19. Fraser-Smith EB, Waters RV, Matthews TR. Correlation between in vivo anti-pseudomonas and anti-candida activities and clearance of carbon by the reticuloendothelial system for various muramyl dipeptide analogs, using normal and immunosuppressed mice. Infect Immun 1982:35; 105-10.

20. Nagao S, Tanaka A. Muramyl dipeptide-induced adjuvant arthritis. Infect Immun 1980:28;624-6.

21. McKercher PD. Oil adjuvants: Their use in veterinary biologics. In: Nervig RM, Gough PM, Kaeberle ML, Whetstone CA, eds. Advances in Carriers and Adjuvants for Veterinary Biologics. Iowa: Iowa State University Press, 1986:115-28.

22. Freund $J$. The mode of action of immunologic adjuvants. Adv Tuberc Res 1956:7;130-48.

23. Glenny AT, Pope GC, Waddington H, Wallace V. Antigenic value of toxoid precipitated by potassium alum. J Pathol Bacteriol 1926:29;38-45.

24. Nicholson KG, Tyrrel DAJ, Harrison P, et al. Clinical studies of monovalent inactivated whole virus and subunit A/USSR/77 $\left(\mathrm{H}_{1} \mathrm{~N}_{1}\right)$ vaccine: Serological and clinical reactions. J Biol Stand 1979:7;123-31.

25. Bomford R. Aluminum salts: Perspectives in their use as adjuvants. In: Gregoriadis G, Allison AC, Poste G, eds. Immunological Adjuvants and Vaccines. New York: Plenum Press, 1989:35-42.

26. Bomford R. Relative adjuvant activity of $\mathrm{A} 1(\mathrm{OH})_{3}$ and saponin is related to the immunogenicity of the antigen. Int Archs Allergy Appl Immun 1984:75;280-1.

27. Vijay HM, Lavregne G, Huang H, Bernstein IL. Preferential synthesis of IgE reaginic antibodies in rats immunized with alum adsorbed antigens. Int Arch Allergy Appl Immunol 1979:59;227-32.

28. Dalsgaard K. A study of the isolation and characterization of the saponin Quil A. Evaluation of its adjuvant activity, with special reference to the application in the vaccination of cattle against foot-and-mouth disease. Acta Vet Scand 1978:69;1-12.

29. Bomford R. Saponins as immunoadjuvants. In: Gregoriadis G, Allison AC, Poste G, eds. Immunological Adjuvants and Vaccines. New York: Pleunum Press, 1989:43-6.

30. Playfair JHL, DeSouza JB. Vaccination of mice against malaria with soluble antigens. I. The effect of injection route and adjuvant. Parasite Immunol 1986:8;409-14.

31. Morein B, Sundquist B, Höglund S, Dalsgaard K, Osterhaus A. ISCOM, a novel structure for antigenic presentation of membrane proteins from enveloped viruses. Nature 1984:308;457-60.

32. Lövgren $\mathrm{K}$, Morein $\mathrm{B}$. The requirement for lipids for the formation of immunostimulating complexes (IScOMs). Biotech Appl Biochem 1988:10;161-72.

33. Morein B, Lövgren K, Höglund S. Immunostimulating complex (ISCOM). In: Gregoriadis G, Allison AC, Poste G, eds. Immunological Adjuvants and Vaccines. New York: Plenum Press, 1989:153-62.

34. Letvin NL, Daniel MD, King NV, et al. AIDS-like disease in macaque monkeys induced by simian immunodeficiency virus: A vaccine trial. In: Chavock RM, Lerner RA, Brown F, Gensberg H, eds. Cold Spring Harbor Laboratory, 1987:209-13.

35. Ellouz F, Adam A, Ciorbaru R, Lederer E. Minimal structural requirements for adjuvant activity of bacterial peptidoglycans. Biochem Bioplays Res Comm 1974:59; 1317.

36. Hunter RL, Strickland F, Kezdy F. The adjuvant activity of nonionic block polymer surfactants. I. The role of hydrophile-lipophile balance. J Immunol 1981:127;1244-50.

37. Rietschel ET, Brade L, Schade V, Seydel V, et al. Bacterial endotoxins: Relationship between chemical structure and biological activity. In: Gregoriadis G, Allison AC, Poste G, eds. Immunological Adjuvants and Vaccines. New York: Plenum Press, 1989:61-74.

38. Imoto M, Yoshimura H, Sakaguchi N, Kusumoto S, Shiba T. Total synthesis of Escherichia coli lipid A. Tetrahedron Lett 1985:26;1545-8.

39. Allison AC, Gregoriadis G. Liposomes as immunological adjuvants. Nature 1974:252:252-3.

40. Gregoriadis G. Immunological adjuvants: A role for liposomes. Immunol Today 1990:11;89-93.

41. Unanue ER, Askonas BA, Allison AC, A role of macrophages in the stimulation of immune responses by adjuvants. J Immunol 1969:103;71-8.

42. Spitznagel JK, Allison AC. Mode of action of adjuvants: Effects on antibody responses to macrophageassociated bovine serum albumin. J Immunol 1970:104; 128-39.

43. Allison AC, Davies AJS. Requirement of thymusdependent lymphocytes for potentiation by adjuvants of antibody formation. Nature 1971:233:330-2.

44. Balfour BM, Drexhage HA, Kamperdijk EW, Hoefsmit EC. Antigen-presenting cells, including Langerhans cells, veiled cells and interdigitating cclls. Ciba Found Symp 1980:84;281-301.

45. Metlay JP, Pure E, Steinman RM. Control of the immune response at the level of antigen-presenting cells: A comparison of the function of dendritic cells and B-lymphocytes. Adv Immunol 1990:47;45-116.

46. Macatonia SE, Knight SC. Dendritic cells and T cells transfer sensitization for delayed-type hypersensitivity after skin painting with contact sensitizer. Immunology 1989:66;96-9.

47. Klaus GG, Humphrey JH, Kunkl A, Dongworth DW. The follicular dendritic cell: Its role in antigen presentation and in the generation of immunological memory. Immunol Rev 1980:53;3-28.

48. Szakal AK, Kosco MH, Tew JG. Microanatomy of lymphoid tissue during humoral immune responses: Structure function relationships. Ann Rev Immunol 1989:7;91-109.

49. Ron Y, Sprent J. T cell primary in vivo: A major role for $\mathrm{B}$-cells in presenting antigen to T-cells in lymph nodes. J Immunol 1987:138;2848-56.

50. White RG. The adjuvant effect of microbial products on the immune response. Ann Rev Microbiol 1976:30;579-600.

51. Finkelman FD, Holmes J, Katona IM, et al. Lymphokine control of in vivo immunoglobulin isotype selection. Ann Rev Immunol 1990:8;303-34.

52. Marx PA, Pedersen NC, Lerche NW, et al. Prevention of simian acquired immunodeficiency syndrome with a 
formalin-inactivated Type D retrovirus vaccine. J Virol 1986:60;431-5.

53. Murphey-Corb M, Martin LN, Davison-Fairburn B, et al. A formalin inactivated whole simian immunodeficiency virus vaccine confers protection in macaques. Science 1989:246; 1293-7.

54. Girard M, Kieny M-P, Pinter A, et al. Immunization of chimpanzees confers protection against challenge with human immunodeficiency virus. Proc Natl Acad Sci USA 1991:88;542-6.

55. Berman PW, Gregory TJ, Crase P, Lasky LA. Protection from genital herpes simplex type 2 infection by vaccination with cloned glycoprotein $\mathrm{D}$. Science 1985:227; 1490-2.

56. Allison AC, Byars NE. Adjuvant formulations and their mode of action. Semin Immunol 1990:2;369-74.

57. Morgan AJ, Allison AC, Finerty S, Scullion FT, Byars NE, Epstein MA. Validation of a first generation Epstein-Barr virus vaccine preparation suitable for human use. J Med Virol 1989:29;74-8.

58. Campbell MJ, Esserman L, Byars NE, Allison AC, Levy R.
Development of a new therapeutic approach to B-cell malignancy. The induction of immumty by the host against cell surface receptor on the tumor. Intern Rev Immunol 1989:4;251-70.

59. Arden NH, Patricarca PA, Kendal AP. Experiences in the use and efficacy of influenza vaccine in nursing homes. In: Kendal AP, Patricarca PA, eds. Options for Control of Influenza. New York: Alan R Liss, 1986:155-68.

60. Byars NE, Allison AC, Harmon MW, Kendal AP. Enhancement of antibody responses to influenza B virus hemagglutinin by use of a new adjuvant formulation. Vaccine 1990:8;49-56.

61. Milich DR, Chisari FV. Genetic restriction of the immune response to hepatitis $\mathrm{B}$ surface antigen (HBsAg). 1 .

Restriction of the murine humoral response to the a and d determinants of HBsAg. J Immunol 1982:129:320-5.

62. Byars NE, Nakano GM, Welch M, Allison AC. Use of Syntex adjuvant formulation to enhance immune responses to viral antigens. In: Gregoriadis G, Allison AC, Poste G, eds. Immunological Adjuvants and Vaccines. New York: Plenum Press, 1991. 


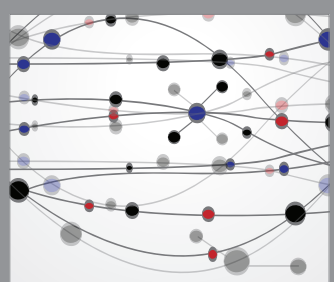

The Scientific World Journal
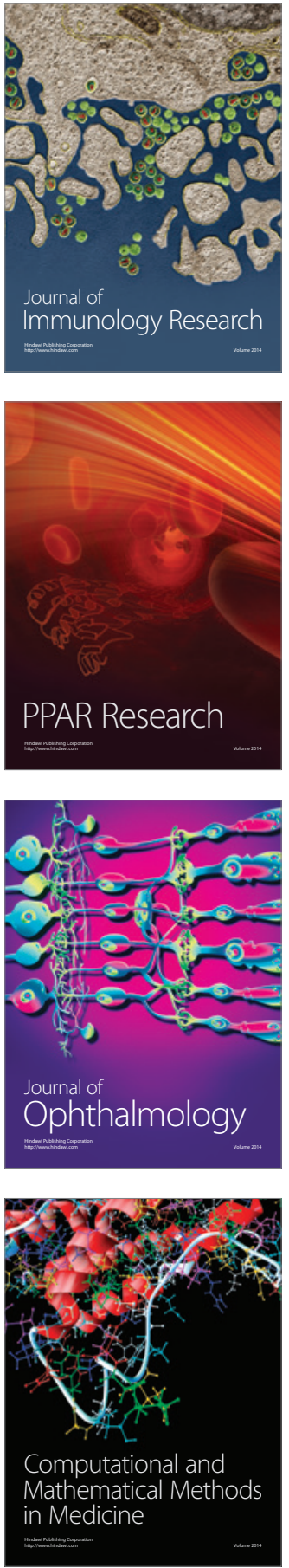

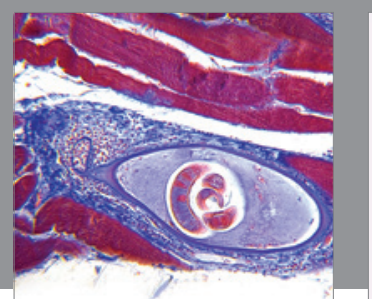

Gastroenterology Research and Practice

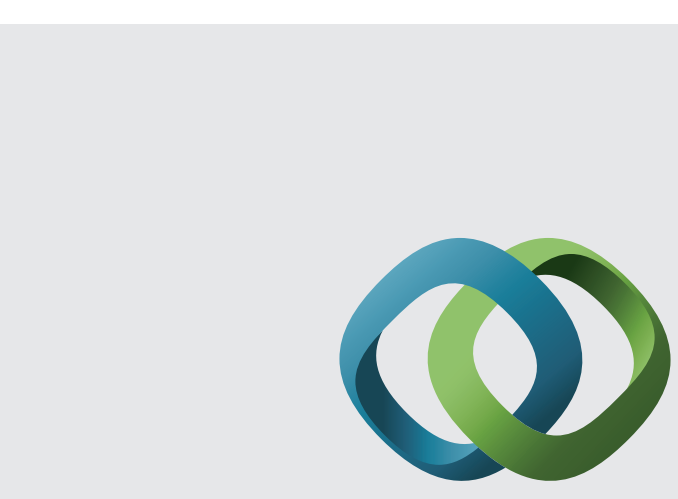

\section{Hindawi}

Submit your manuscripts at

http://www.hindawi.com
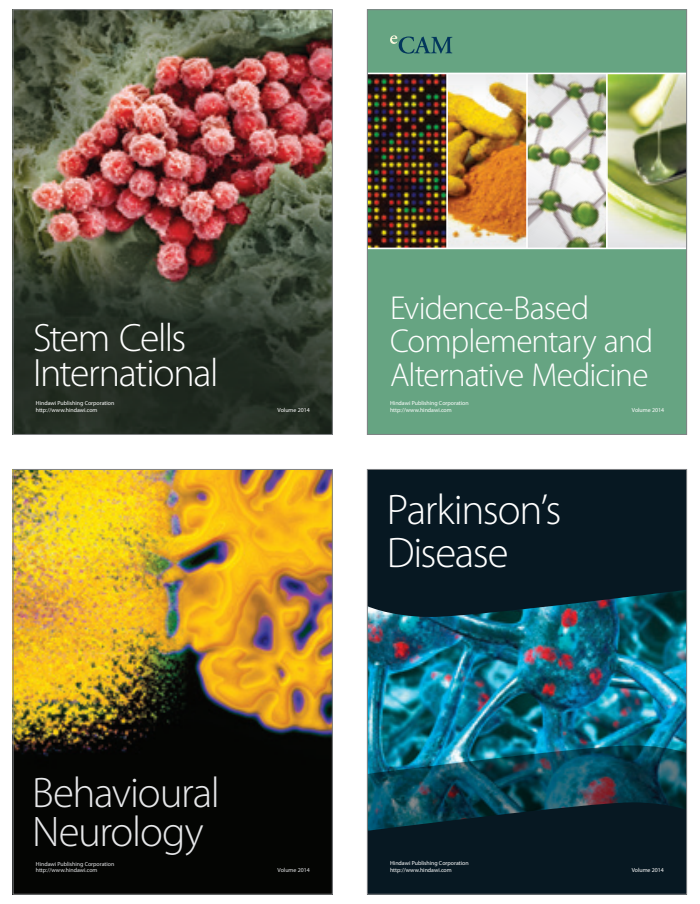
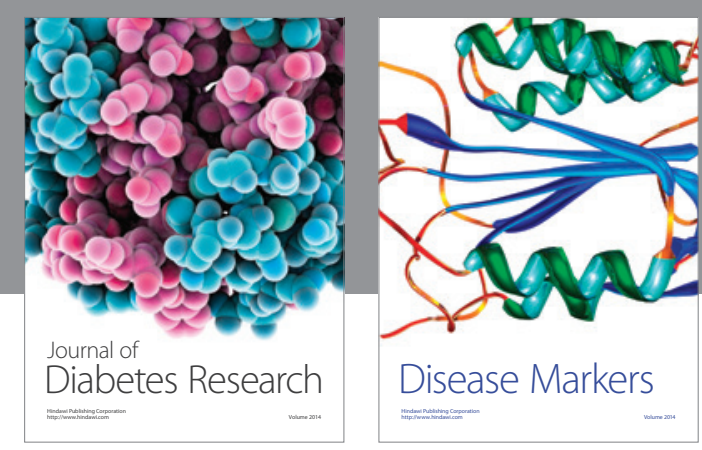

Disease Markers
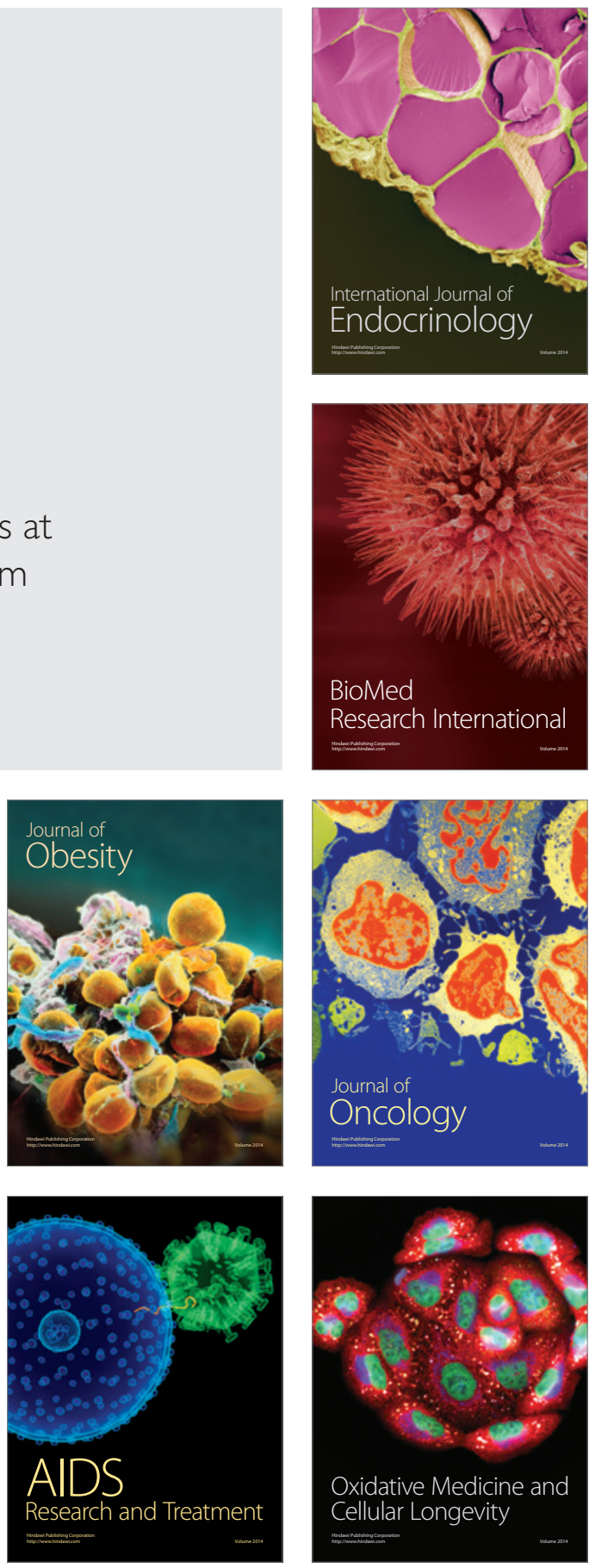